\title{
BIOLOGICAL CONTROL
}

\section{RAPD Analysis Revealing Polymorphism in Egg Parasitoids of Soybean Stink Bugs (Hemiptera: Pentatomidae)}

\author{
Salah M. Aluanabi ${ }^{1}$, Marta S. Loiácono ${ }^{2}$, Rodrigo T. Lourenço ${ }^{1}$, Miguel Borges ${ }^{1}$ \\ AND MYrian S. TiganO ${ }^{1}$ \\ ${ }^{1}$ Embrapa-Cenargen, Caixa postal 02372, 70849-970, Brasília, DF, Brasil. \\ ${ }^{2}$ Departamento Científico de Entomología. Museo de La Plata. 1900 La Plata, \\ Buenos Aires, Argentina.
}

An. Soc. Entomol. Brasil 27(3): 413-420 (1998)

Análise de RAPD Revelando Polimorfismo em Parasitóides de Ovos de Percevejos da Soja (Hemiptera: Pentatomidae)

RESUMO - Parasitóides de ovos (Hymenoptera: Scelionidae) do complexo de percevejos da soja (Glycine max L.) são candidatos potenciais a agentes de controle nos programas de manejo integrado de pragas da soja no Brasil. A correta identificação de espécies e/ou raças desses parasitóides é importante para implementação do uso do controle biológico. A técnica de "random amplified polymorphic DNA" (RAPD) foi usada para analisar indivíduos machos de Telenomus podisi Ashmead e Trissolcus spp. coletado em uma área de soja em Brasília em 1996. A análise de 18 oligonucleotídeos usados para os indivíduos de Trissolcus spp. revelou diferentes perfis de RAPD entre as espécies, indicando a possibilidade de utilizar esses marcadores para diferenciar $T$. teretis Johnson, T. urichi Crawford e T. basalis (Wollaston). Os 13 oligonucleotídeos usados para analisar 33 indivíduos de uma população de T. podisi produziram 103 bandas. Foram observados diferentes genótipos nessa população, que pela análise fenética com os dados de RAPD se agruparam com alta homogeneidade ( similaridade $>78,2 \%$ ).

PALAVRAS-CHAVE: Insecta, microhimenóptero, variabilidade genética, marcadores moleculares, RAPD.

ABSTRACT - The solitary egg parasitoids (Hymenoptera: Scelionidae) of Pentatomidae species complex are potential candidates for soybean (Glycine max L.) integrated pest management programs in Brazil. The correct identification of species and strains of these parasitoids is necessary to implement the use of biological control. Polymerase chain reaction (PCR) was used to generate random amplification of polymorphic DNA (RAPD) from male individuals of Telenomus podisi Ashmead and Trissolcus spp. collected in a soybean field in Brasília, Brazil in 1996. The analysis of 18 primers used to screen Trissolcus spp. individuals revealed different patterns related to the species analyzed. These results indicate the potential of RAPD markers to differentiate T. teretis Johnson, T. urichi Crawford and T. basalis (Wollaston). The 13 selected primers used to 
analyze $T$. podisi individuals produced 103 clear polymorphic scorable markers. Different genotypes were observed within this population analyzed, although the cluster analysis applied to the RAPD data showed high homogeneity (similarity $>78.2 \%$ ) among individuals.

KEY WORDS: Insecta, microhymenoptera parasitoids, genetic variability, molecular markers, RAPD.

The family Scelionidae (Hymenoptera) is composed of egg parasitoids, and includes different species related to important complexes of pentatomid pests of soybean (Glycine $\max$ L.) crops around the world. In Brazil, the most important members of the complex are Nezara viridula (L.), Piezodorus guildinii (Westwood) and Euschistus heros (Fabr.). Telenomus podisi Ashmead and Trissolcus basalis (Wollaston) are the most frequently observed scelionid egg parasitoids species in populations of these pests in the South and the Central area of Brazil, and represent potential candidates for use as biological control agents in soybean pest management programs (Foerster \& Queiroz 1990, Corrêa-Ferreira \& Moscardi 1995, Medeiros et al. 1997). Inoculative releases of T. basalis in the field have successfully reduced and delayed stink bug populations (Corrêa-Ferreira \& Moscardi 1996).

The identification of microhymenoptera is difficult due to their small size and the lack of clear morphological differences between closely related species. The genus Telenomus and Trissolcus are also considered complex to characterize, given the number of Neotropical species that are still very little studied. Johnson (1992) listed 68 Telenomus species from the Neotropics. T. podisi belongs to the monophyletic species group podisi (Johnson 1984). The Neotropical fauna of Trissolcus consists of species of the flavipes (Johnson 1987) and thyantae (Johnson 1985a) groups and a more heterogeneous assemblage of species related to T. basalis (Johnson 1985b). Attempts have been made to subdivide these two large genera, into species groups, but the lineages and their relationships are still far from clear (Johnson 1996).

As the proper identification of species, the detection and identification of differences at species-level can be important for a successful biological control program. However, the morphological characterization used for classification of these pentatomid egg parasitoids is unable to provide an easy and rapid species identification, and to give information about genetic variability within species.

The technique of random amplified polymorphic DNA (RAPD; Williams et al. 1990), also known as arbitrarily primed polymerase chain reaction (AP-PCR; Welsh \& McClelland 1990), has been employed as a powerful tool for DNA fingerprintings and genetic variability analysis of insects (Haymer 1994). As this technique requires small amount of DNA, it becomes the method of choice to perform single insect genetic analyses of small insects, like microhymenoptera parasitoids (Edwards \& Hoy 1993, Landry et al. 1993, Roehrdanz et al. 1993).

In this study, RAPD analysis was evaluated for its ability to detect polymorphism among the most common egg parasitoids found in pentatomid population of a soybean field in Brasília, central region of Brazil. Our aim was to provide new tools for species identification and to use RAPD approach to estimate intraspecific variability.

\section{Material and Methods}

Field Survey. A survey was carried out in a soybean field to evaluate occurrence and genetic variability of solitary egg parasitoids species of the soybean stink bug complex. The field experiment was conducted from August 
1 to December 11 , in a 1 hectare soybean field in Brasília, Central Brazil. Host egg batches were randomly collected throughout the crop once a week. This collecting routine was undertaken from the beginning to the final period of the field experiment. The egg parasitoids emerging from egg batches were divided into two parts, one kept at $-80^{\circ} \mathrm{C}$ for molecular analysis and another placed in tubes with in $70 \%$ alcohol for taxonomic identification.

Parasitoid Identification. Specimens of Telenomus and Trissolcus spp. were mounted on the tips of triangular card points to maximize the surface area available for observation. Methods of dissection and preparation of male genitalia were as usual (Johnson 1984). Telenomus and Trissolcus species characterization was made based on identification keys established by Johnson, 1984 and 1985b, 1987 respectively. The holotypes of $T$. podisi, T. teretis and T. urichi were obtained from U. S. National Museum of Natural History, Washington DC (USNM). Voucher specimens were deposited in the collection of the Departamento Científico de Entomología, Museo de La Plata, La Plata, Argentina.

DNA Extraction. DNA was extracted from insects kept at $-80^{\circ} \mathrm{C}$. For each egg batch one individual male was selected, except for samples A32, A34, A37, A39, A44, A45, A54, A57, A58 and A72 for which two specimens were used. A single step DNA extraction method was used according to by Black et al. (1992) with few modifications. Each individual insect was ground in a $1.5 \mathrm{ml}$ microcentrifuge tube with $56 \mathrm{ml}$ of extraction buffer (5mM Tris- $\mathrm{HCl}$ and $0.5 \mathrm{mM}$ EDTA pH 8.0) using a disposable micropestle, after which $3 \mathrm{ml}$ of Triton - 100 (0.5\% final concentration) and $1 \mathrm{ml}$ of $20 \mathrm{mg} / \mathrm{ml}$ proteinase $\mathrm{K}$ were added and mixed. The samples were incubated at $65^{\circ} \mathrm{C}$ for $15 \mathrm{~min}$, followed by 10 min at $95^{\circ} \mathrm{C}$ to inactivate proteinase $\mathrm{K}$. The tubes containing the DNA solution were spun for 5 seconds and then stored at $-80^{\circ} \mathrm{C}$ until needed. The amount of DNA in each sample was estimated around 700-1000ng, enough to perform several PCR reactions.

RAPD Analysis. The PCR reactions were performed in a $50 \mathrm{ml}$ volume containing $2 \mathrm{ml}$ of previously prepared template DNA solution (approximately 15 - 25ng of DNA), 2 units of Taq polymerase (Cenbiotec), $5 \mathrm{ml}$ of 10x polymerase's recommended buffer, 200 $\mathrm{mM}$ of each dNTP (Pharmacia), and $0.4 \mathrm{mM}$ primer. The reactions mixture were overlaid with $50 \mathrm{ml}$ of mineral oil. Amplification was carried out in 96-well PCR plates using the PTC-100 programmable thermal cycler (MJ Research). The temperature profile used was one step at $94^{\circ} \mathrm{C}$ for 3 minutes, followed by 45 cycles of $93^{\circ} \mathrm{C}$ for $1 \mathrm{~min}, 35^{\circ} \mathrm{C}$ for $1 \mathrm{~min}$ and $72^{\circ} \mathrm{C}$ for $2 \mathrm{~min}$, with final extension step at $72^{\circ} \mathrm{C}$ for $5 \mathrm{~min}$. The reactions were maintained at $15^{\circ} \mathrm{C}$ until electrophoresis. PCR products were electrophoresed in $2 \% \mathrm{LE}$ agarose gel prepared in $0.5 \mathrm{x}$ Tris-boratoEDTA (TBE) buffer, stained with ethidium bromide (Sambrook et al., 1989), and photographed under UV light.

DNA samples from two individuals of each species, T. podisi, T. basalis and T. teretis, were used to screen thirty-four 10-mer primers (Operon Technologies, Alameda, CA). Primers were selected for this study based on their ability to produce easily distinguishable polymorphism within or between species. Thirteen primers (OPB-5, OPB-6, OPB-7, OPB-12, OPC-2, OPC-4, OPC-5, OPC-8, OPC-9, OPC-11, OPC-12, OPC-19, and OPC-20) were used to analyze T. podisi specimens. For the analysis of the Trissolcus spp. individuals, the following eighteen primers were used: OPC-1, OPC-2, OPC-4, OPC-8, OPC-9, OPC-11, OPC-13, OPC-14, OPC-18, OPC-19, OPC-20, OPB-3, OPB-5, OPB-6, OPB-7, OPB-10, OPB-12 and OPB-14.

Data Analysis. DNA fingerprints were scored directly from the photographs. Only well resolved products were scored. The presence or absence of each fragment was considered as an independent character. RAPD markers were analyzed using NTSYS-pc V1.8 (Rohlf, 
1993). A similarity matrix was calculated using Jaccard similarity coefficient (Sneath \& Sokal 1973) which does not consider the joint absence of a marker as an indication of similarity. Clustering was done using the unweighted mean pair group arithmetic mean method (UPGMA) (Sneath \& Sokal 1973).

\section{Results and Discussion}

Morphological identification of parasitoids collected showed that the species present in the experimental area of soybean consisted of $74 \%$ T. podisi, $15 \%$ Trissolcus teretis Johnson, 6\% Trissolcus urichi Crawford, and $5 \%$ T. basalis $(\mathrm{N}=287 \mathrm{egg}$ masses collected). The principal host was Piezodorus guildinii (Westwood) representing $75 \%$ of the pentatomid fauna collected $(\mathrm{N}$ =196). In some cases, the presence of more than one species of parasitoids on egg batches was observed (data not shown), as already recorded by Medeiros et al. (1997). To avoid contamination, only samples with one species were used for molecular analysis. From the total of individual males collected from $P$. guildinii egg mass, 33 specimens of T. podisi, 13 specimens of $T$. teretis, 12 specimens of $T$. urichi and 6 specimens of T. basalis were selected for molecular analysis.

The RAPD markers proved to be an efficient method to differentiate the most common species of Trissolcus found in a soybean pentatomid pest population, T. basalis, T. teretis and T. urichi. The morphological characters used for classification of these parasitoids are not always easy and practical to separate species, specially between $T$. teretis and T. urichi, that are included in the same monophyletic group, flavipes. However, all eighteen primers used to study the 31 specimens of Trissolcus spp. produced RAPD patterns that clearly distinguished the three species analyzed (example of fingerprinting data shown in Fig. 1). In fact, the average pairwise similarity within specimens of the same species was $87.7,65.2$ and $70.8 \%$ to $T$. teretis, $T$. urichi and $T$. basalis respectively (data not

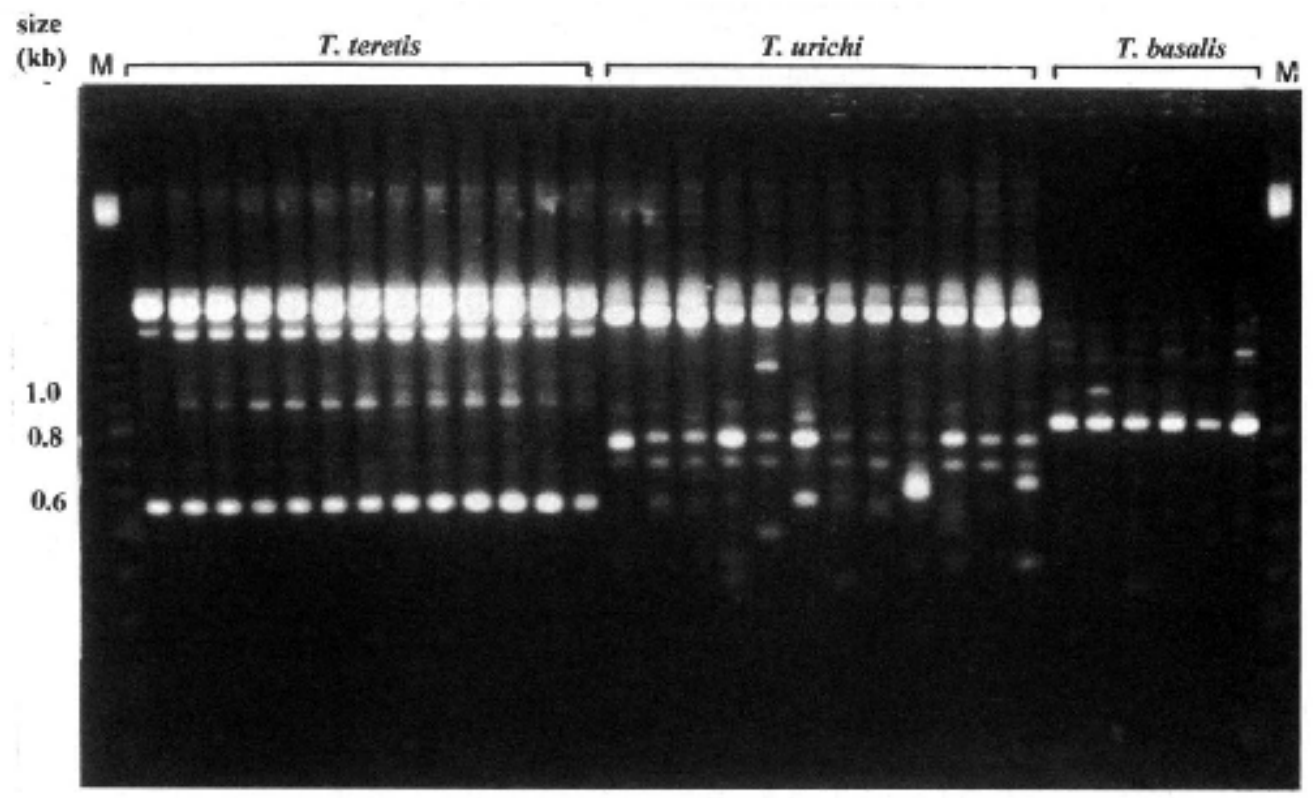

Figure 1. An example of an agarose gel showing results from RAPD fingerprinting of 31 Trissolcus spp. specimens using OPC-4 primer. M=molecular mass markers. The species display a banding pattern completely different from each other with the same primer. 
showed). These results indicated that the difficulty to recognize morphological differences among these species could be overcomed by the comparison of profiles obtained by RAPD analysis. RAPD markers were also observed as promising for a rapid and easy species identification of the microhymenoptera parasitoids of genus Trichogramma (VanlerbergheMasutti 1994).

Regarding the specimens of T. podisi (Table 1), a total of 103 bands were scored with acters did not show clear phenetic groups within the $T$. podisi individuals analyzed. They clustered with more than 78\% similarity (Fig. 2). This low polymorphism observed suggests that the population of the $T$. podisi can be quite homogeneous in the same soybean area. However, other populations should be analyzed to understand the genetic variability of $T$. podisi. In fact, Johnson (1992) considered that $T$. podisi is a highly variable species, especially in the tropics. In this case, our results indi-

Table 1. Samples of Telenomus podisi obtained from Piezodorus guildinii egg masses collected from soybean field in Brasília, Brazil, in 1996.

\begin{tabular}{lclc}
\hline Sample/Replicate & Collection date & Sample/Replicate & Collection date \\
\hline A30 & $10 / 14$ & A45/2 & $10 / 22$ \\
A31 & $10 / 10$ & A51 & $10 / 24$ \\
A32/1 & $10 / 14$ & A54/1 & $10 / 22$ \\
A32/2 & $10 / 14$ & A54/2 & $10 / 22$ \\
A33 & $10 / 14$ & A55 & $10 / 22$ \\
A34/1 & $10 / 14$ & A56 & $10 / 22$ \\
A34/2 & $10 / 14$ & A57/1 & $10 / 24$ \\
A37/1 & $10 / 21$ & A57/2 & $10 / 24$ \\
A37/2 & $10 / 21$ & A58/1 & $10 / 25$ \\
A38 & $10 / 14$ & A58/2 & $10 / 25$ \\
A39/1 & $10 / 17$ & A62 & $10 / 24$ \\
A39/2 & $10 / 17$ & A64 & $10 / 24$ \\
A42 & A70 & $10 / 31$ \\
A43 & $10 / 21$ & A71 & $10 / 31$ \\
A44/1 & $10 / 21$ & A72/1 & $11 / 25$ \\
A44/2 & $10 / 21$ & A72/2 & $11 / 25$ \\
A45/1 & $10 / 21$ & & \\
\hline
\end{tabular}

${ }^{1}$ In some cases more than one individual was used from each sample.

the 13 selected primers, averaging 7.9 marker per primer. Different genotypes were detected, even in the cases of individuals from the same host egg batch, as most of the samples undertaken in this study (Fig. 2). Those genotypes could represent individuals from different females, regarding the fact that the same host egg batch have been parasitised by different species of scelionids parasitoid (Medeiros et al. 1997). Cluster analysis of the RAPD char- cated that RAPD markers could be a useful tool to analyze geographical populations of T. podisi and to resolve eventual taxonomic questions about this species. The observation of different biotypes of this parasitoid may also represent differences on their agressivity as biological control agent.

Our results suggested that the RAPD technique could provide a powerful tool to improve species identification and to better un- 


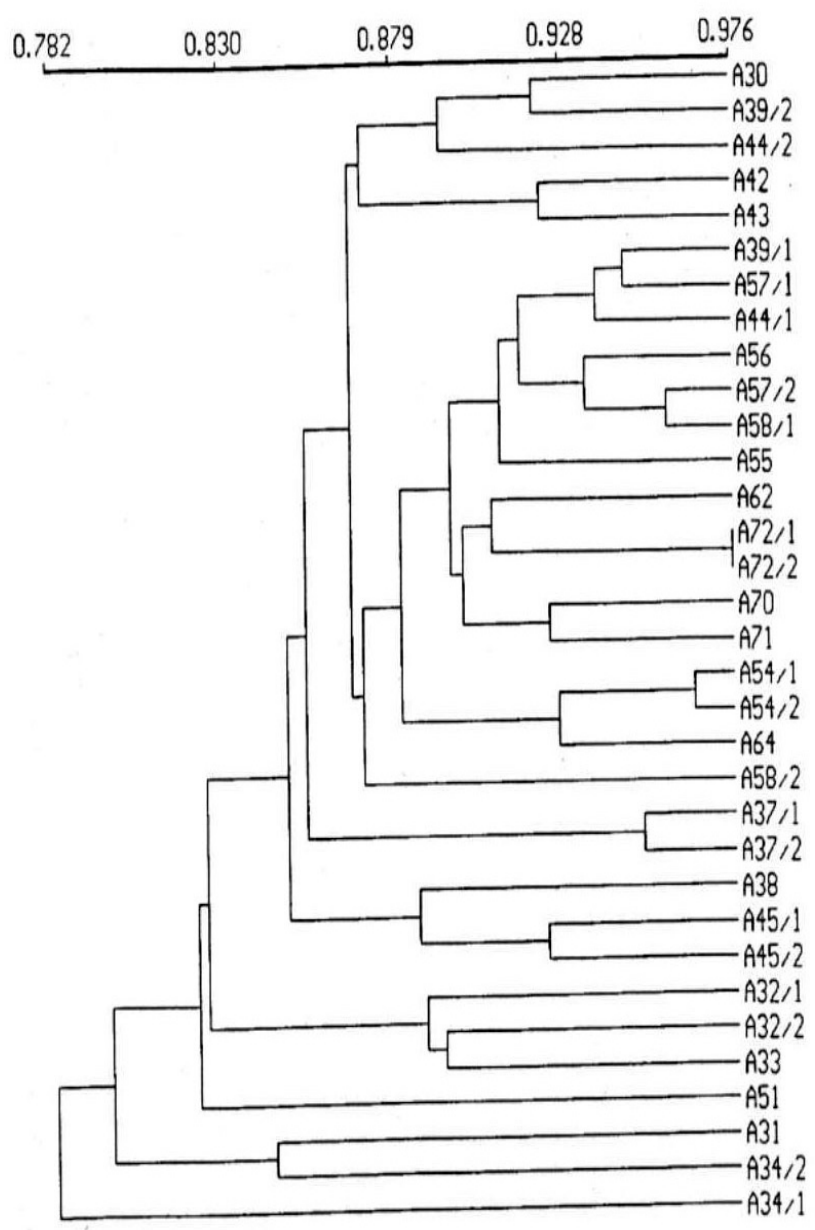

Figure 2. Dendrogram constructed from the RAPD data indicating the relationships among Telenomus podisi male individuals obtained from Piezodorus guildinii egg masses. One individual was used for each egg batch, except for the samples A32, A34, A37, A39, A44, A45, A54, A57, A58 and A72 in which two specimens were used. A similarity matrix was calculated using the Jaccard coefficient. The UPGMA dendrogram was generated from the similarity matrix.

derstanding the genetic variability of stink bug egg parasitoids. It is important, when using parasitoids in a biological control program, to undoubtedly identify species in the natural population in order to design strategies for monitoring releases in the environment. Besides, RAPD analysis could also be used to monitor quality control of mass-rearing of these insects.

\section{Acknowledgments}

We thank D. R. Smith (National Museum of Natural History, Smithsonian Institution, 
Washington, USA), N. F. Johnson (Ohio State University, Columbus, Ohio, USA) and A. A. Lanteri (Museo de La Plata, La Plata, Argentina) for the kind supply of type material and information, G. G. Soares (Mycogen Corporation, San Diego, CA, USA), R. D. G. Carneiro (Embrapa/CPACT, Pelotas, RS, Brazil) and B. Magalhães (Embrapa/Cenargen, Brasília, DF, Brazil) for critical review of the manuscript. This work was supported by the Conselho Nacional de Pesquisa e Desenvolvimento Científico (CNPq) and Empresa Brasileira de Pesquisa Agropecuária (Embrapa). S. M. Aljanabi and R. T. Lourenço were supported by CNPq.

\section{Literature Cited}

Black, W.C., N.M. DuTeau, G.J. Puterka, J.R. Nechols \& J.M. Pettorini. 1992. Use of the random amplified polymorphic DNA polymerase chain reaction (RAPDPCR) to detect DNA polymorphisms in aphids. Bull. Entomol. Res. 82: 151-159.

Corrêa-Ferreira, B.S. \& F. Moscardi. 1995. Seasonal occurrence and hosts spectrum of egg parasitoids associated with soybean stink bugs. Biol. Control 5: 196202.

Corrêa-Ferreira, B.S. \& F. Moscardi. 1996. Biological control of soybean stink bugs by inoculative releases of Trissolcus basalis. Entomol. Exp. Appl. 79: 1-7.

Edwards, O. R. \& M.A. Hoy. 1993. Polymorphism in two parasitoids detected using random amplified polymorphic DNA polymerase chain reaction. Biol. Control 3: 243-257.

Foerster, L.A. \& J.M. Queiroz. 1990. Incidência natural de parasitismo em ovos de pentatomídeos da soja no Centro-Sul do Paraná. An. Soc. Entomol. Brasil 19: 221-232.

Haymer, D. S. 1994. Arbitrary (RAPD) primer sequences used in insect studies. Insect Mol. Biol. 3: 191-194.

Johnson, N. F. 1984. Systematics of Neartic Telenomus: classification and revisions of the podisi and phymatae species groups (Hymenoptera: Scelionidae). Bull. Ohio. Biol. Surv. 6, 113 p.

Johnson, N. F. 1985a. Revision of the New World species of the thyantae group of Trissolcus (Hymenoptera: Scelionidae). Can. Entomol. 117: 107-112.

Johnson, N. F. 1985b. Systematics of New World Trissolcus (Hymenoptera : Scelionidae) species related to T. basalis. Can. Entomol. 117: 431- 445.

Johnson, N. F. 1987. Systematics of New World Trissolcus, a genus of pentatomid egg-parasites (Hymenoptera: Scelionidae): Neotropical species of the flavipes group. J. Nat. Hist. 21: 285-304.

Johnson, N. F. 1992. Catalog of world species of Proctotrupoidea, exclusive of Platygastridae (Hymenoptera). Mem. Am. Entomol. Inst. 51: 825p.

Johnson, N. F. 1996. Revision of the world species of Paratelenomus Dodd (Hymenoptera: Scelionidae). Can. Entomol. 128: 273-291.

Landry, B., L. Dextraze \& G. Boivin. 1993. Random amplified polymorphic DNA markers for fingerprinting and genetic variability assessment of minute parasitic wasp species used in biological control programs of phytophagous insects. Genome 36: 580-587.

Medeiros, M.A., F.V.G. Schimidt, M.S. Loiácono, V.F. Carvalho \& M. Borges. 1997. Parasitismo e predação em ovos de Euschistus heros (Fab.) (Hemiptera: Pentatomidae) no Distrito Federal. An. Soc. Entomol. Brasil 26: 397-401. 
Roehrdanz, R. L., Reed, D. K. and Burton, R. L. 1993. Use of polymerase chain reaction and arbitrary primers to distinguish laboratory-raised colonies of parasitic hymenoptera. Biol. Control 3: 199-206.

Rohlf, F. J. 1993. NTSYS-pc v. 1.8. Numerical taxonomy and multivariate analysis system. Applied Biostatistics Inc. Setauket, NY, 191p.

Sambrook, J., E.F. Fritsch \& T. Maniatis. 1989. Molecular cloning: a laboratory manual. 2nd ed., NY, Cold Spring Harbor Laboratory Press.

Sneath, P.A. \& R. R. Sokal. 1973. Numerical Taxonomy. Freeman, San Francisco, 573p.

Vanlerberghe-Masutti, F. 1994. Molecular identification and phylogeny of parasitic wasp species (Hymenoptera: Trichogrammatidae) by mitocondrial DNA RFLP and RAPD markers. Insect Mol. Biol. 3: 229-237.

Welsh, J. \& M. McClelland. 1990. Fingerprinting genomes using PCR with arbitrary primers. Nucleic Acids Res. 18: 7213-7218.

Williams, J.G.K., A.R. Kubelik, K.J., Livak, J.A. Rafalsk \& S.V. Tingy. 1990. DNA polymorphisms amplified by arbitrary primers are useful as genetic markers. Nucleic Acids Res. 18: 65316535 .

Received 24/VII/97. Accepted 07/V/98. 